\title{
PENGARUH MOTIVASI DAN LINGKUNGAN KELUARGA MELALUI SELF EFFICACY TERHADAP MINAT MENJADI GURU
}

\author{
Renita Sari, ${ }^{\otimes}$ Rusdarti
}

Jurusan Pendidikan Ekonomi, Fakultas Ekonomi, Universitas Negeri Semarang, Indonesia

\section{Info Artikel}

Sejarah Artikel:

Diterima, 9 April 2020

Disetujui, 17 Juni 2020

Dipublikasikan, 31

Agustus 2020

\section{Keywords:}

Lingkungan Keluarga,

Minat Menjadi Guru,

Motivasi Diri, Self Efficacy

\begin{abstract}
Abstrak
Tujuan penelitian ini adalah untuk mengetahui pengaruh motivasi diri dan lingkungan keluarga terhadap minat menjadi guru baik secara langsung maupun tidak langsung melalui self efficacy sebagai variabel mediasi. Metode penelitian menggunakan metode kuantitatif dengan analisis jalur dan uji sobel. Subjek penelitian ini adalah seluruh mahasiswa Pendidikan Ekonomi angkatan tahun 2014 dengan populasi sebesar 399 dan kemudian diambil sampel sebanyak 100 responden. Metode pengumpulan data menggunakan kuesioner. Hasil penelitian menunjukkan (1) Motivasi diri berpengaruh positif terhadap self efficacy sebesar 21,9\%, (2) Lingkungan keluarga berpengaruh negatif terhadap self efficacy sebesar 32,03\%, (3) Pengaruh total motivasi diri terhadap minat menjadi guru melalui self efficacy sebesar $41,2 \%$, (4) Pengaruh total lingkungan keluarga terhadap minat menjadi guru melalui self efficacy sebesar $-20,38 \%$, (5) Self efficacy berpengaruh positif terhadap minat menjadi guru sebesar $16,16 \%$. Saran penelitian ini diharapkan mahasiswa pendidikan ekonomi untuk lebih mengenal minatnya menjadi guru dan mencari pengetahuan dan informasi tentang profesi guru memadai.
\end{abstract}

\section{Abstract}

This study aims to investigate the effect of self-motivation and family environment on the interest in becoming teachers directly or indirectly through self-efficacy as a mediator variable. The research method employed was quantitative method with path analysis and Sobel test. The subjects of this study were all students of Economics Education Faculty of Economics, Universitas Negeri Semarang year 2014 with a population of 399 and a sample of 100 respondents. The method used was of data collection used questionnaires. The results show that (1) self-motivation positively affects self-efficacy by $21.9 \%$. (2) Family environment negatively affects self-efficacy by $32.03 \%$. (3) The total effect of self-motivation on the interest in becoming teachers through selfefficacy is $41.2 \%$. (4) The total effect of family environment on the interest in becoming teachers through self-efficacy is-20.38\%. (5) Self-efficacy positively affects the interest in becoming teachers by $16.16 \%$. The suggestions of this study are students of economics education should know more about their interests in becoming teachers and should seek adequate knowledge and information about teacher profession. In addition, family should not give excessive attention and treatment to children because it can reduce the children's abilities.

\begin{tabular}{lr}
\hline Alamat korespondensi: & p-ISSN 2723-4495 \\
Gedung L2 FE UNNES & e-ISSN 2723-4487 \\
Kampus Sekaran, Gunungpati, Semarang, 50229 & \\
E-mail: Renitasari22@gmail.com &
\end{tabular}




\section{PENDAHULUAN}

Pendidikan adalah kunci pembangunan bagi bangsa Indonesia di masa mendatang.Dengan adanya pendidikan diharapkan setiap individu dapat meningkatkan kualitas dirinya dan mampu berpartisipasi dalam gerak pembangunan Negara Indonesia.Oleh karena itu pendidikan dijadikan sebagai transmisi ilmu pengetahuan dan teknologi untuk meningkatkan kualitas sumber daya manusia. Salah satu cara yang harus dilakukan untuk mendapatkan sumber daya manusia yang berkualitas yaitu dengan mempunyai pendidik atau guru yang berkualitas.

Guru adalah pendidik profesional dengan tugas utama mendidik, mengajar, membimbing, mengarahkan, melatih, dan mengevaluasi peserta didik pada jalur pendidikan formal, pada jenjang pendidikan dasar, dan pendidikan menengah (Surya, 2013:354). Profesi guru merupakan profesi strategis untuk mengembangkan output atau lulusan yang memiliki sumber daya yang berkualitas untuk mencerdaskan kehidupan bangsa Indonesia. Mengingat tugas utama guru yang cukup penting dalam sistem pendidikan, seorang guru harus memiliki kualifikasi tertentu agar dapat melaksanakan tugasnya dengan baik.Oleh karena itu pekerjaan guru tidak dapat dilakukan oleh sembarang orang diluar bidang pendidikan. Guru harus menjalani pendidikan di perguruan tinggi dan memilih program studi yang berlatar belakang pendidikan serta memiliki empat kemampuan dasar yang harus dikuasai oleh calon guru yaitu kompetensi pedagogik, kompetensi kepribadian, kompetensi professional, dan kompetensi sosial. Untuk itu diharapkan bagi calon guru untuk memiliki pengetahuan yang luas dan kepribadian yang unggul.

Selain kompetensi, minat untuk menjadi guru juga harus ditumbuhkan sejak dini bagi calon guru, paling tidak saat mereka akan masuk ke perguruan tinggi dan mengambil program kependidikan. Minat merupakan salah satu faktor yang ikut menentukan keberhasilan seseorang baik dalam hal studi, pekerjaan, maupun aktivitas yang lain. Menurut Slameto (2010:188) minat adalah suatu rasa lebih suka dan rasa ketertarikan pada suatu hal atau aktivitas, tanpa ada yang menyuruh.Sedangkan menurut Djaali (2013:121) minat dapat diekspresikan melalui pernyataan yang menunjukkan bahwa siswa lebih menyukai suatu hal daripada hal lainnya, dapat pula dimanifestasikan melalui partisipasi dalam suatu aktivitas.

Banyak ahli yang mengemukakan pendapatnya mengenai minat yang berbedabeda, namun pada dasarnya semua itu merupakan pendapat yang saling melengkapi satu sama lain. Oleh karena itu, minat dapat diartikan sebagai ketertarikan pada suatu aktivitas yang meliputi tiga aspek yaitu aspek pertama kognisi yang meliputi pengetahuan dan informasi yang memadai mengenai profesi guru, aspek kedua yaitu emosi yang meliputi perasaan senang dan ketertarikan terhadap profesi guru.Ketiga yaitu konasi yaitu meliputi kemauan atau hasrat untuk berprofesi menjadi guru.Berkaitan dengan minat menjadi guru maka dapat dikatakan sebagai ketertarikan seseorang pada profesi guru ditunjukan dengan pemusatan pikiran, perasaan senang, dan perhatian yang lebih pada profesi guru dan pada akhirnya memiliki hasrat kehendak untuk berprofesi sebagai guru.

Profesionalitas guru juga harus terus dikembangkan untuk meningkatkan kemampuannya sebagai pendidik.Setiaji (2015:197) menyatakan bahwa peningkatan profesionalisme guru yang ada saat ini di fokuskan pada profesionalisme guru dalam jabatan (in-servvice teacher training).Semestinya langkah tersebut diimbangi dengan peningkatan kualitas penyiapan tenaga kerja guru (pre-service teacher training). Salah satunya pada input mahasiswa calon guru, perlu memperhatikan aspek psikologi seperti minat dan motivasi selain aspek intelektual untuk mendapatkan input yang baik.

Lembaga Pendidikan Tenaga Pendidik (LPTK) adalah perguruan tinggi 
yang diberi tugas untuk menyelenggarakan program keguruan.LPTK memiliki andil dalam menyiapkan calon guru yang mampu bekerja secara kompeten.Akan tetapi berdasarkan data Kemdikbud menyatakan bahwa jumlah LPTK di Indonesia saat ini berjumlah 421 LPTK dengan jumlah lulusan sarjana sekitar 260.000 orang.Namun, yang terserap PPG hanya berkisar 27.000 orang setiap tahunnya.Sarjana pendidikan yang tidak terserap menjadi guru professional tersebut tentunya tidak hanya disebabkan karena minimnya kuota pengangkatan, tetapi juga karena mutu lulusan yang masih dibawah standar.Untuk mengukur kompetensi yang dimiliki oleh seorang guru, pemerintah mengadakan Uji Kompetensi Guru (UKG).UKG ini menguji kompetensi guru untuk dua bidang, yaitu bidang pedagogik dan profesional. Berdasarkan hasil uji kompetensi nasional tahun 2017 yang diikuti oleh 2.035 peserta, 38 persen guru yang dinyatakan lulus sementara 62 persen dinyatakan tidak lulus. $\mathrm{Hal}$ ini mengidentifikasikan bahwa kompetensi guru sebagai tenaga pendidik profesional di Indonesia perlu ditingkatkan lagi.

Universitas Negeri Semarang (UNNES) merupakan LPTK yang berperan sebagai lembaga penyelenggara program pendidikan bagi calon guru untuk mencetak tenaga profesional.Jurusan pendidikan ekonomi adalah jurusan kependidikan di Fakultas Ekonomi (FE) UNNES.Pendidikan ekonomi memiliki visi menjadi program studi bereputasi internasional, sebagai pusat keunggulan pendidikan, penelitian, dan pengabdian kepada masyarakat dalam bidang ekonomi dengan menjunjung tinggi etika, kejujuran, dan tanggung jawab sosial.Salah satu tujuannya yaitu untuk menghasilkan lulusan yang kompeten, memiliki kemampuan akademik, dan professional dibidang pendidikan ekonomi sesuai dengan perkembangan ilmu pengetahuan dan teknologi.

Untuk menghasilkan guru yang professional dibidangnya, minat merupakan salah satu kesiapan mental yang harus dimiliki oleh calon guru.Sebagai mahasiswa calon guru yang menempuh pendidikan di UNNES tentunya harus mendapatkan bekal yang memadai agar dapat mengajar dengan baik secara teoritis dan praktis.Akan tetapi sebagian besar mahasiswa lulusan pendidikan ekonomi lebih memilih untuk bekerja pada perusahaan, bank-bank swasta maupun negeri dan tidak memilih profesi guru sesuai latar belakang pendidikannya karena jurusan pendidikan ekonomi dianggap sebagai jurusan yang lebih fleksibel dibandingkan jurusan lainnya. Hal ini tentunya tidak sesuai dengan tujuan jurusan pendidikan ekonomi untuk menghasilkan calon guru ekonomi yang profesional

Berdasarkan data tracer study tahun 2016 menunjukkan bahwa persentase mahasiswa pendidikan ekonomi yang bekerja di instansi pendidikan sebesar $27,7 \%$, bank sebesar 1.2\%, dunia industri sebesar 40,4\% wirausaha sebesar $1,2 \%$, dan yang lainnya bekerja di bidang lainnya sebesar $29,5 \%$. Hal ini menunjukkan bahwa lulusan pendidikan ekonomi FE UNNES yang bekerja sesuai dengan jurusannya hanya $27,7 \%$ dan sebagian besar lainnya bekerja di luar instansi pendidikan.

Hasil survey awalmahasiswa pendidikan ekonomi FE UNNESangkatan 2014 menunjukkan bahwa 5,41\% mahasiswa sangat berminat untuk menjadi guru dengan alasan karena mereka memiliki keinginan untuk menjadi guru. Sebesar 54,05\% mahasiswa berminat menjadi guru dengan alasan karena dorongan dari orang tua dan menganggap profesi guru adalah pekerjaan yang mulia. Sebesar $29,73 \%$ mahasiswa raguragu untuk menjadi guru alasan dengan alasan karena mereka ingin bekerja diluar profesi guru, menganggap profesi guru bukan sebagai prioritas utama, dan mereka menganggap bahwa menjadi guru bukan keahlian mereka. Sebesar 10,81\% mahasiswatidak berminat untuk menjadi guru dengan alasan karena mereka menganggap bahwa profesi guru memiliki tanggung jawab yang besar dan juga mereka tidak memiliki kompetensi guru. Hal ini membuktikan bahwa mahasiswa pendidikan ekonomi FE UNNES masih terdapat 
keraguan dalam dirinya untuk berprofesi menjadi guru.

Di duga minat menjadi guru salah satunya dipengaruhi oleh motivasi diri yang dimiliki oleh mahasiswa, khususnya mahasiswa pendidikan ekonomi FE UNNES.Motivasi adalah dorongan yang terdapat dalam diri seseorang untuk berusaha mengadakan perubahan tingkah laku yang lebih baik dalam memenuhi kebutuhannya (Hamzah, 2008:3).Subini menyatakan motivasi sebagai dorongan yang timbul pada diri seseorang yang entah disadari atau tidak untuk melakukan suatu tindakan dengan tujuan tertentu.Dilihat dari jenisnya, motivasi dapat dilihat dari dua sudut pandang yaitu motivasi yang berasal dari dalam diri pribadi seseorang yang disebut motivasi intrinsik dan motivasi yang berasal dari luar diri seseorang yang disebut motivasi ekstrinsik (Wahab 2015:129).Dengan demikian motivasi diri adalah dorongan yang berasal dari dalam diri seseorang untuk menentukan tujuan yang diinginkannya. Motivasi diri yang dimiliki oleh mahasiswa akan memunculkan rasa ketertarikan yang berasal dari dalam dirinya untuk berprofesi sebagai guru.

Mahasiswa yang memiliki motivasi dari dalam dirinya akan lebih bersemangat untuk menjalani aktivitasnya dibandingkan dengan mahasiswa yang tidak memiliki motivasi. Mahasiswa tersebut akan lebih terdorong untuk mempelajari tentang dunia pendidikan, sehingga ada motivasi dari dalam diri mahasiswa untuk mengikuti pembelajaran dengan sungguh-sungguh di bangku kuliah tentang dunia pendidikan. Oleh karena itu, dengan adanya motivasi diri yang dimiliki mahasiswa tentang dunia pendidikan diharapkan dapat meningkatkan minat mahasiswa untuk menjadi guru.

Belum optimalnya minat mahasiswa menjadi guru dapat disebabkan oleh motivasi diri mahasiswa.Rendahnya motivasi mahasiswa pendidikan ekonomi FE UNNES diduga dari kurangnya hasrat (keinginan), kemampuan, dan cita-cita untuk menjadi guru.Hal inilah yang menyebabkan motivasi diri mahasiswa rendah. Penelitian Shalihah
(2016) menunjukkan bahwa minat menjadi guru dipengaruhi oleh motivasi belajar sebesar 28,8\%. Dalam penelitian Wildan dkk (2016) menunjukkan hasil bahwa minat menjadi guru dipengaruhi oleh motivasi internal dan motivasi eksternal.

Selain motivasi diri faktor lain yang diduga mempengaruhi minat menjadi guru adalah lingkungan keluarga mahasiswa, khususnya mahasiswa pendidikan ekonomi FE UNNES. Lingkungan secara psikologis mencakup segenap stimulasi yang diterima oleh individu mulai sejak dalam kosesi, kelahiran sampai matinya (Dalyono, 2015:128). Dalam proses belajar, lingkungan keluarga memiliki peranan yang utama sebelum guru dan pendidikan di sekolah. Dari keluarga, anak mendapatkan pendidikan awal untuk membekali kehidupannya, seperti pendidikan budi pekerti, akhlak, dan pendidikan akademiknya. Lingkungan keluarga yang harmonis menggunakan pola asuh demokratis dimana orang tua selalu memprioritaskan kepentingan anak tetapi juga memberikan pengawasan bagi anakanaknya, sehingga selain anak memiliki kebebasan untuk memilih profesi sesuai minatnya dan orang tua tetap memiliki pengendaliannya bagi anak-anaknya.

Lingkungan keluarga merupakan tempat terjadinya proses sosialisasi yang dijadikan sebagai pedoman bagi anak dalam menentukan jenjang kariernya. Seperti yang telah diketahui bahwa mahasiswa UNNES, khususnya pendidikan ekonomi FE berasal dari berbagai macam lingkungan keluarga.Ada mahasiswa yang berasal dari keluarga pendidik, dimana seluruh anggota keluarganya bekerja sebagai guru dan adapula mahasiswa yang berasal dari keluarga wiraswasta.Perbedaan profesi inilah yang diduga menjadi penentu minat mahasiswa untuk berprofesi sebagai guru.

Minat merupakan salah satu elemen yang diturunkan oleh orang tua secara genetis, sehingga mahasiswa yang mempunyai keluarga seorang guru akan mempunyai minat yang tinggi untuk menjadi seorang guru. Akan tetapi banyak juga guru 
yang pada mulanya terutama pada masa kecilnya adalah orang-orang yang tidak berasal dari keluarga guru, pendidikan yang relatif tidak tinggi, serta bukan dari keluarga yang mampu.Tantangan yang dihadapi itu lah yang memberikan kontribusi bagi terbentuknya jiwa pendidik bagi mahasiswa.

Penelitian terkait minat menjadi guru yang dilakukan oleh Febrianto (2016) menyatakan bahwa minat menjadi guru dipengaruhi oleh lingkungan keluarga secara positif dan signifikan sebesar 21,62\%. Sedangkan penelitian Hikmah (2017) menunjukkan bahwa minat menjadi guru dipengaruhi oleh lingkungan keluarga secara negatif dan signifikan sebesar 5,62\%. Hal inilah yang membuat peneliti akan mengkaji ulang variabel lingkungan keluarga terhadap minat menjadi guru.

Dengan adanya fenomena dan perbedaan hasil penelitian tentang motivasi diri dan lingkungan keluarga terhadap minat menjadi guru, menjadi dasar menambahkan self efficacy sebagai variabel mediasi antara motivasi diri dan lingkungan keluarga terhadap minat menjadi guru. Self efficacy atau keyakinan tentang kemampuan seseorang untuk menyelesaikan tugas-tugas tertentu mempengaruhi seseorang memilih untuk belajar dan mencapai tujuan yang mereka tetapkan untuk diri mereka sendiri mempunyai empat sumber yakni kinerja masa lalu, pengalaman vikarius, persuasi verbal, dan isyarat emosional (Bandura dalam Lunenburg, 2011).Seseorang dengan self efficacy tinggi, akan berusaha dengan maksimal untuk mencapai tujuan yang ingin di raih. Ketika seorang guru bisa mengajarakan ilmu dan mendidik siswanya dengan baik maka guru tersebut telah mencapai pencapaian yang ditargetkan dan akan berusaha menetapkan pencapaian yang lebih tinggi lagi dari pencapaian sebelumnya. Bagi mahasiswa pendidikan khususnya pendidikan ekonomi, self efficacy sangat dibutuhkan untuk keberhasilan pencapaian ilmu pengetahuan yang telah didapatkan selama di bangku kuliah.Rendahnya self efficacy dilihat dari ketidakyakinan dari mahasiswa dalam menghadapi suatu tantangan. Penelitian yang dilakukan Astarini (2015) menunjukkan bahwa minat menjadi guru dipengaruhi oleh self efficacy sebesar 43,29\%. Hal ini senada dengan penelitian Wahyuni (2017) yang menunjukkan bahwa self efficacy berpengaruh terhadap minat menjadi guru sebesar 38,07\%.

Tujuan penelitian ini adalah untuk mengetahui: (1) pengaruh motivasi diri terhadap self efficacy pada mahasiswa pendidikan ekonomi FE UNNES. (2) pengaruh lingkungan keluarga terhadap self efficacy pada mahasiswa pendidikan ekonomi FE UNNES. (3) Pengaruh motivasi diri terhadap minat menjadi guru baik langsung maupun tidak langsung melalui self efficacy pada mahasiswa pendidikan ekonomi FE UNNES. (4) Pengaruh lingkungan keluarga terhadap minat menjadi guru baik langsung maupun tidak langsung melalui self efficacy pada mahasiswa pendidikan ekonomi FE UNNES. (5) Untuk mengetahui pengaruh self efficacy terhadap minat menjadi guru pada mahasiswa pendidikan ekonomi FE UNNES.

\section{METODE}

Penelitian ini termasuk penelitian kuantitatif.Populasi dalam penelitian ini adalah seluruh mahasiswa Pendidikan Ekonomi FE UNNES angkatan 2014 yang berjumlah 399 mahasiswa.Pengambilan sampel menggunakan pendapat Suharsimi sebesar 25\% dari jumlah populasi sehingga diperoleh sebanyak 100 mahasiswa.Data diambil dengan kuesioner dengan teknik pengambilan sampelnya adalah Simple Random Sampling.Penelitian menggunakan analisis deskriptif dan analisis jalur (path analysis).

\section{HASIL DAN PEMBAHASAN}

Analisis deskriptif statistik menunjukkan bahwa variabel minat menjadi guru mahasiswa Pendidikan Ekonomi pada kategori tinggi, motivasi diri pada kategori tinggi, lingkungan keluarga pada kategori baik, dan self efficacy pada kategori tinggi.

Pengaruh motivasi diri dan lingkungan keluarga terhadap minat menjadi guru baik langsung maupun tidak langsung melalui self efficacy dapat dilihat dari hasil analisis jalur. 
Analisis jalur dalam penelitian ini minat menjadi guru dengan self efficacy sebagai digunakan untuk menganalisis pengaruh variabel mediasi.Hasil analisis jalur dapat motivasi diri dan lingkungan keluargaterhadap dilihat pada tabel dibawah ini.

Tabel 1. Hasil Analisis Regresi Berganda dengan Self Efficacy sebagai Variabel Terikat

\begin{tabular}{lccccc}
\hline \multicolumn{1}{c}{ Variabel } & $\begin{array}{c}\text { Stand. } \\
\text { Coefficients } \\
\text { Beta }\end{array}$ & t Hitung & Sig. & R Square & $\begin{array}{c}\text { Adj. R } \\
\text { Square }\end{array}$ \\
\hline Motivasi Diri & 0,469 & 7,454 & 0,000 & 0,626 & 0,618 \\
Lingkungan Keluarga & $-0,566$ & $-9,000$ & 0,000 & & \\
\hline
\end{tabular}

Sumber: Data penelitian diolah

Persamaan regresi yang diperoleh:

$\mathrm{X}_{3}=0,469 \mathrm{X}_{1}-0,566 \mathrm{X}_{2}+0,611$

Nilai $e_{2}$ sebesar 0,611 merupakan variance variabel self efficacy yang tidak dapat dijelaskan oleh variabel motivasi diri dan lingkungan keluarga. Hasil analisis regresi berganda dalam penelitian ini menggunakan hasil dari

Standardized Coefficients Beta yang berarti nilai satuan dari setiap variabel dianggap sama, sehingga dalam persamaan regresi tidak menggunakan nilai Constant. Sedangkan hasil analisis regresi berganda dengan minat menjadi guru sebagai variabel terikat dapat dilihat pada tabel dibawah ini.

Tabel 2.Hasil Analisis Regresi Berganda dengan Minat Menjadi Guru sebagai Variabel Terikat

\begin{tabular}{lcccccc}
\hline \multicolumn{1}{c}{ Variabel } & $\begin{array}{c}\text { Stand. } \\
\text { Coefficients } \\
\text { Beta }\end{array}$ & t Hitung & Sig & F Hitung & $\begin{array}{c}\mathrm{R} \\
\text { Square }\end{array}$ & $\begin{array}{c}\text { Adj. R } \\
\text { Square }\end{array}$ \\
\hline Motivasi Diri & 0,473 & 6,969 & 0,000 & & & 0,717 \\
Lingkungan Keluarga & $-0,154$ & $-2,101$ & 0,038 & 84,723 & 0,726 & \\
Self Efficacy & 0,135 & 4,601 & 0,000 & & & \\
\hline
\end{tabular}

Sumber: Data penelitian diolah

Persamaan regresi yang diperoleh:

$\mathrm{Y}=0,473 \mathrm{X} 1-0,154 \mathrm{X} 2+0,402 \mathrm{X} 3+0,523$

Nilai $e_{2}$ sebesar 0,523 merupakan variance variabel minat menjadi guru yang tidak dapat dijelaskan oleh variabel motivasi diri, lingkungan keluarga, dan self efficacy. Hasil analisis regresi berganda dalam penelitian ini menggunakan hasil dari Standardized Coefficients Beta yang berarti nilai satuan dari setiap variabel dianggap sama, sehingga dalam persamaan regresi tidak menggunakan nilai Constant.

Berdasarkan model regresi diatas diperoleh model hasil regresi sebagai berikut:

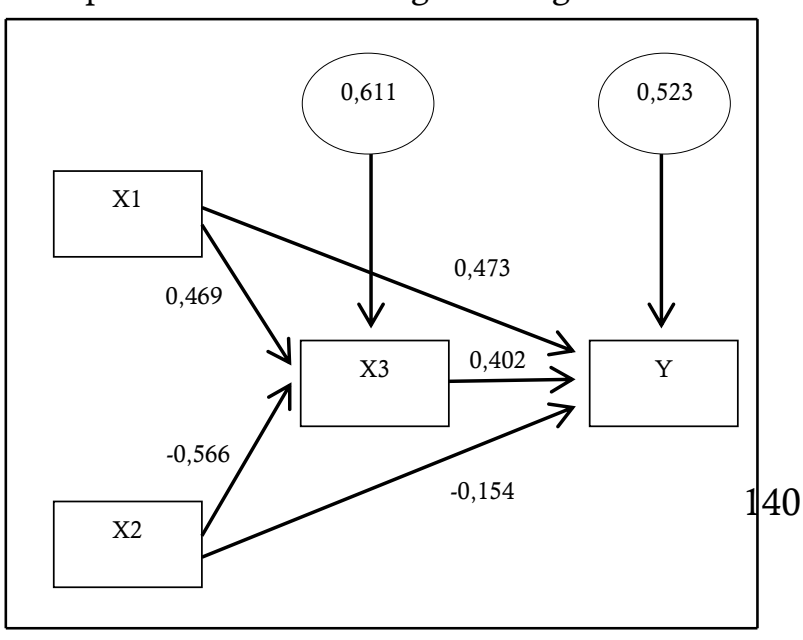

Gambar 2.Persamaan Regresi

Pengaruh Motivasi Diri terhadap Self Efficacy Hasil penelitian menunjukkan motivasi diri berpengaruh positif dan signifikan terhadap self efficacy mahasiswa pendidikan ekonomi FE UNNES sebesar 21,99\%. Hal ini membuktikan bahwa motivasi diri berperan penting dalam memberikan dorongan pada mahasiswa untuk meningkatkan self efficacy.Semakin tinggi motivasi diri maka semakin tinggi self efficacy pada mahasiswa.

Pengaruh motivasi diri mahasiswa terhadap self efficacy didukung masing-masing indikator variabel motivasi diri. Indikator yang paling dominan adalah hasrat dan keinginan 
berhasil, indikator ini mendeskripsikan bagaimana keinginan kuat yang dimiliki mahasiswa untuk mencapai keberhasilannya, sehingga hasrat dan keinginan yang tinggi akan meningkatkan kepercayaan diri mahasiswa terhadap kemampuannya. Indikator selanjutnya adalah dorongan dan kebutuhan, indikator ini mendeskripsikan bagaimana dorongan dan kebutuhan mahasiswa untuk menyelesaikan tugas-tugas yang dianggap sulit, sehingga akan membuat mahasiswa lebih bersemangat dalam mengerjakannya. Indikator harapan dan citacita masa depan, menerangkan bahwa motivasi diri dapat meningkatkan harapan mahasiswa untuk meraih cita-cita masa depannya.

Hal ini didukung pendapat Bandura bahwa motivasi adalah konstruk kognitif yang mempunyai dua sumber, gambaran hasil pada masa yang akan datang (yang dapat menimbulkan motivasi tingkah laku saat ini), dan harapan keberhasilan didasarkan pada pengalaman menetapkan dan mencapai tujuan-tujuan antara (dalam Alwisol, 2009:364). Dengan kata lain, harapan mendapat reinforsemen pada masa yang akan datang memotivasi seseorang untuk bertingkah laku tertentu. Juga dengan menetapkan tujuan atau tingkat performansi yang diinginkan, dan kemudian mengevaluasi performansi dirinya, maka individu akan termotivasi untuk bertindak pada tingkat tertentu. Motivasi diri akan mendorong tingkah laku individu untuk mencapai tujuan yang diinginkan, sehingga akan membawa individu berada pada rasa self efficacy yang tinggi dan mereka akan percaya dengan kemampuan yang ada pada diri mereka untuk mencapai tujuan dan cita-cita masa depan.

Hamzah (2008:1) berpendapat bahwa motivasi adalah dorongan dasar yang menggerakkan seseorang bertingkah laku, dorongan ini berada pada diri seseorang yang menggerakkan untuk melakukan sesuatu yang sesuai dengan dorongan dalam dirinya. Mahasiswa yang termotivasi dari dalam dirinya cenderung akan mencapai tujuannya dengan semaksimal mungkin. Karena mahasiswa tersebut memberi dorongan atau motivasi pada dirinya sendiri dan mengarahkan tindakannya melalui tahap pemikiran-pemikiran yang telah dilakukan sebelumnya. Kepercayaan akan kemampuan diri dapat mempengaruhi motivasi mahasiswa dalam beberapa hal, yakni menentukan tujuan yang telah ditetapkan sebelumnya, seberapa besar usaha yang dilakukan mahasiswa dan ketahanan mereka dalam menghadapi kesulitan-kesulitan dan ketahanan mereka dalam menghadapi kegagalan yang mungkin terjadi.

Hasil penelitian ini menguatkan penelitian Jailani (2017) bahwa motivasi berprestasi memiliki pengaruh terhadap selfefficacy.Sementara Amir (2016) dalam penelitiannya menunjukkan bahwa motivasi berprestasi juga memiliki pengaruh signifikan terhadap self efficacy. Dengan demikian mahasiswa akan meningkatkan kemampuan yang dimilikinya apabila mahasiswa tersebut memiliki motivasi dari dalam dirinya untuk mencapai tujuan yang ingin dicapai.

\section{Pengaruh Lingkungan Keluarga terhadap Self Efficacy}

Hasil penelitian menunjukkan lingkungan keluarga berpengaruh negatif dan signifikan terhadap self efficacy mahasiswa pendidikan ekonomi FE UNNES sebesar $32,03 \%$. Hal ini membuktikan bahwa lingkungan keluarga berperan penting dalam memberikan perhatian terhadap anak dan menjadi panutan bagi anaknya dalam berperilaku.Semakin baik lingkungan keluarga maka semakin rendah selfefficacy yang dimiliki mahasiswa.

Pengaruh lingkungan keluarga terhadap self efficacy didukung masing-masing indikator variabel lingkungan keluarga. Indikator yang paling dominan adalah cara orang tua mendidik, indikator ini mendeskripsikan bahwa cara orang tua mendidik anak yang baik dalam keluarga dapatmenurunkanself efficacy anak tersebut. Hal ini dapat terjadi karena orang tua yang terlalu memanjakan anaknya (mahasiswa) akan membuat anak tersebut sulit untuk berkembang, sehingga hal terebut dapat menurunkan kemampuan anaknya. Indikator selanjutnya latar belakang 
kebudayaan mendeskripsikan bagaimana keluarga menanamkan kebiasaan yang baik agar dapat mendorong anaknya untuk menumbuhkan kepercayaan terhadap kemampuan yang dimilikinya, dalam hal ini anak cenderung bersikap sesuai dengan kebiasaan yang mereka dapatkan ketika berada diluar lingkungan keluarga, sehingga anak cenderung lebih bersikap seperti yang terjadi di luar lingkungan keluarganya.

Pada indikator suasana rumah, indikator ini mendeskripsikan bahwa situasi atau kejadian yang sering terjadi didalam keluarga akan mempengaruhi self efficacy mahasiswa, dalam hal ini lingkungan keluarga yang tidak baik, akan membuat anak menginginkan adanya perubahan. Sehingga anak tersebut akan berusaha meningkatkan kemampuan dirinya untuk mengubah kondisinya menjadi lebih baik. Indikator terendah yaitu pengertian orang tua, indikator ini mendeskripsikan bagaimana orang tua memahami kondisi anaknya, apakah anak mengalami kesulitan atatu tidak, orang tua yang tidak memberi perhatian kepada anaknya akan membuat anak tersebut bertindak sesuai dengan keinginan mereka sendiri tanpa memperdulikan orang tuanya. Berdasarkan indikator lingkungan keluarga cara orang tua mendidik memberikan pengaruh yang tinggi bagi mahasiswa untuk meningkatkan kemampuan yang dimilikinya.

Self efficacy dapat diperoleh, diperkuat, atau dilemahkan melalui persuasi sosial (Alwisol, 2009:289).Pada kondisi yang tepat, persuasi sosial dapat mempengaruhi self efficacy.Kondisi ini adalah rasa percaya pada pemberi persuasi dan sifat realistik dari apa yang dipersuasikan. Lingkungan keluarga merupakan tempat pertama dan utama bagi pembentukan kepribadian anak melalui pemberian dukungan emosional, dukungan penghargaan, dukungan instrumental, dan dukungan informatif yang mempengaruhi tingkat self efficacy yang dimiliki oleh anak tersebut. Lingkungan keluarga yang baik akan membawa seseorang berada pada self efficacy yang rendah, mereka yakin dengan kemampuan yang ada pada diri mereka sendiri untuk mencapai tujuan yang diinginkannya.
Lingkungan keluarga memiliki peran penting dalam pembentukan kepribadian anak.Memberi perhatian kepada anak adalah hal yang wajar dan memiliki banyak dampak positif bagi hubungan antara keluarga dengan anaknya, salah satu dampaknya adalah terciptanya ikatan emosional antara orang tua dengan anaknya menjadi lebih kuat. Namun terlepas dari banyaknya dampak positif, tidak dapat dipungkiri bahwa ketika keluarga memberikan perhatian dan perlakuan yang berlebih pada anak justru akan memicu munculnya karakter negatif pada pribadi dan sikap anak, misalnya saja akan memunculkan karakter "manja" pada diri anak. Rasa khawatir yang berlebih, membuat keluarga terutama orang tua cukup meminimalisir tantangan dan gangguan pada anaknya, alhasil anak selalu dibuat menikmati zona nyaman (comfort zone) yang justru dapat mengganggu kemampuan yang ada pada diri anak. Sehingga akan menurunkan tingkat self efficacy dalam diri anak. Akan tetapi apabila lingkungan keluarganya kurang baik justru akan membuat anak memiliki self efficacy yang tinggi. Karena kondiri lingkungan keluarga yang dirasa kurang baik akan memicu anak untuk mengubah kehidupannya menjadi lebih baik lagi sehingga akan meningkatkan selfefficacy yang ada dalam dirinya.

Hasil penelitian ini sejalan dengan penelitian Teintang, dkk (2015) yang menemukan bahwa sikap orang tua yang terlalu memanjakan anak dapat menghasilkan kepribadian anak pemalas.Sementara Bandura dalam Alwisol (2009:363) yang berpendapat bahwa sumber pengontrol tingkah laku adalah resiprokal antara lingkungan, tingkah laku, dan pribadi.Self efficacy merupakan variabel pribadi yang penting kalau digabung dengan tujuan-tujuan spesifik dan pemahaman mengenai prestasi, akan menjadi penentu tingkah laku mendatang yang penting. Self efficacy yang tinggi bila dikombinasikan dengan lingkungan yang tidak responsif, akan menghasilkan tingkah laku yang berusaha keras untuk mengubah lingkungan menjadi responsif dan memaksakan adanya perubahan yang terjadi dalam dirinya. 
Pengaruh Motivasi Diri terhadap Minat Menjadi Guru Baik Langsung Maupun Tidak Langsung Melalui Self Efficacy

Hasil uji hipotesis tentang pengaruh motivasi diri terhadap minat menjadi guru melalui uji statistik memperoleh nilai sig. 0,000 $<0,05$, yang berarti bahwa motivasi diri $\left(\mathrm{X}_{1}\right)$ berpengaruh signifikan terhadap minat menjadi guru (Y), sedangkan hasil analisis jalur untuk pengaruh tidak langsung motivasi diri $\left(\mathrm{X}_{1}\right)$ terhadap minat menjadi guru (Y) dengan dimediasi self efficacy yaitu sebesar 41,22\%. Adapun dengan uji sobel yang mana nilai $t$ hitung $>\mathrm{t}$ tabel yaitu $2,727>1,660$, sehingga dapat dikatakanmempunyai pengaruh tidak langsung signfikan.Berarti bahwa variabel mediasi self efficacy diterima sebagai variabel mediasi antara motivasi diri terhadap minat menjadi guru.

Adanya pengaruh motivasi diri terhadap minat menjadi guru membuktikan kebenaran teori perilaku terencana atau theory of planned behavior (TPB).Teori ini menjelaskan bahwa perilaku individu terlebih dahulu dipengaruhi oleh minat. Minat akan dipengaruhi oleh tiga faktor utama yaitu sikap terhadap perilaku, norma subjektif, dan kontrol perilaku persepsian yang dapat berdampak pada perilaku. Minat menjadi guru merupakan perilaku dengan keterlibatan tinggi (high involment), karena dalam mengambil keputusan akan melibatkan faktor internal seperti kepribadian, persepsi, motivasi, pembelajaran (sikap), faktor seperti keluarga, teman, tetangga, dan lain sebagainya (norma subjektif). Adanya motivasi akan meningkatkan minat mahasiswa untuk menjadi guru.

Motivasi adalah dorongan yang terdapat dalam diri individu untuk berusaha mengadakan perubahan tingkah laku yang lebih baik dalam memenuhi kebutuhannya (Hamzah, 2008:3).Sementara Dalyono (2015:57) menyatakan bahwa motivasi sebagai penggerak atau pendorong untuk melakukan suatu pekerjaan. Mahasiswa akan terdorong untuk berusaha berprofesi sebagai guru. Hal ini sesuai dengan apa yang diharapkannya untuk mencapai cita-citanya dimasa yang akan datang. Mahasiswa yang memiliki minat untuk menjadi guru akan terdorong semangatnya untuk berusaha lebih maksimal untuk mengembangkan kemampuannya sebagai calon guru.

Hasil penelitian ini menguatkan hasil penelitian Shalihah (2016) yang menemukan bahwa motivasi berprestasi berpengaruh terhadap minat menjadi guru.Hasil penelitian Wildan dkk (2016) juga menunjukkan bahwa terdapat pengaruh yang signifikan motivasi intrinsik dan ekstrinsik terhadap minat menjadi guru.Dalam penelitian ini self efficacy sebagai variabel mediasi antara motivasi diri terhadap minat menjadi guru mahasiswa diterima. Hal ini sesuai dengan teori Bandura (1997) bahwa perilaku dapat dimediasi oleh self efficacy melalui proses kognitif, motivasi, afeksi, dan seleksi (Wahyudin, 2015:106). Mahasiswa harus mempunyai self efficacy yang tinggi agar terwujudnya suatu pilihan untuk berprofesi menjadi guru.

Guru merupakan salah satu pilihan pekerjaan. Mahasiswa harus mempunyai self efficacy yang tinggi agar dapat menentukan pilihan pekerjaannya sendiri tanpa adanya paksaan dari pihak manapun dan sesuai dengan minat yang dimilikinya. Tinggi rendahnya motivasi diridipersepsikan akan merubah pola perilaku individu untuk bertindak lebih baik dan terarah dalam mencapai tujuan yang hendak dicapainya. Oleh karena itu dengan melalui self efficacy, motivasi diri mempunyai kontribusi terhadap minat mahasiswa untuk menjadi guru. Hal ini berarti semakin tinggi motivasi diri mahasiswa dengan diperkuat self efficacy, maka akan semakin tinggi minat mahasiswa untuk menjadi guru.

\section{Pengaruh Lingkungan Keluarga terhadap Minat Menjadi Guru Baik Langsung Maupun Tidak Langsung Melalui Self Efficacy}

Hasil hipotesis tentang pengaruh lingkungan keluarga terhadap minat menjadi guru melalui uji statistik memperoleh nilai sig. $0,038<0,05$ yang berarti bahwa lingkungan keluarga $\left(\mathrm{X}_{2}\right)$ berpengaruh signifikan terhadap minat menjadi guru $(\mathrm{Y})$ sedangkan hasil analisis jalur untuk pengaruh tidak langsung lingkungan keluarga $\left(\mathrm{X}_{2}\right)$ terhadap minat menjadi guru $(\mathrm{Y})$ dengan dimediasi self 
efficacyyaitu sebesar $-20,38 \%$. Adapun dengan uji sobel yang mana nilai $t$ hitung $<t$ tabel yaitu $-2,484<1,660$.Dengan demikian pengaruh tidak langsung negatif dan signifikan.Berarti bahwa variabel mediasi self efficacy diterima sebagai variabel mediasi antara lingkungan keluarga terhadap minat menjadi guru.

Pengaruh lingkungan keluarga terhadap minat menjadi guru membuktikan kebenaran Theory of Planned Behavior (Ajzen, 2005) yang menyatakan bahwa perilaku seseorang terlebih dahulu dipengaruhi oleh minat. Minat akan dipengaruhi tiga faktor, salah satunya yaitu norma subjektif. Norma subjektif adalah persepsi seseorang mengenai tekanan sosial untuk melakukan atau tidak melakukan perilaku. Perilaku seseorang tergantung niat, kemudian niat dalam berperilaku tergantung pada norma subjektif. Lingkungan keluarga merupakan faktor eksternal (norma subjektif) dalam penentuan keputusan untuk berprofesi menjadi guru.

Keluarga merupakan lembaga pendidikan pertama dan utama (Slameto, 2010).Keluarga menjadi lingkungan pendidikan pertama yang diterima oleh anak, sehingga keluarga memiliki peranan yang penting dalam dalam upaya mengembangkan pribadi anak. Lingkungan keluarga didukung oleh beberapa indikator antara lain cara orang tua mendidik, relasi antar anggota keluarga, suasana rumah, keadaan ekonomi orang tua, pengertian orang tua, dan latar belakang kebudayaan. Pengaruh langsung lingkungan keluarga terhadap minat menjadi guru menunjukkan hasil bahwa semakin baik lingkungan keluarga maka semakin rendah minat mahasiswa untuk menjadi guru.

Lingkungan keluarga memegang
peranan penting dalam memberikan pandangan mengenai nilai-nilai dalam kehidupan sehari-hari dan juga dalam hal memilih pekerjaan.Perhatian dan kebiasaan dalam keseharian lingkungan keluarga serta intensitas hubungan antara keluarga dengan anak (mahasiswa) memiliki peranan penting dalam menentukan pekerjaan anaknya. Pengaruh langsung lingkungan keluarga menunjukkan lingkungan keluarga yang baik akan mengakibatkan rendahnya minat menjadi guru. Sehingga perhatian dan kebiasaan dalam keseharian keluarga serta intensitas hubungan antara keluarga dengan anak memiliki peranan penting dalam menentukan pekerjaan anaknya. Perhatiaan dan kebiasaan yang baik dalam keluarga akan membuat minat mahasiswa untuk menjadi guru menurun. Misalnya anak yang berasal dari lingkungan keluarga yang berprofesi sebagai guru akan membuat anaknya untuk memilih profesi yang lebih tinggi dari profesi keluarganya, seperti berprofesi sebagai pejabat atau profesi lainnya yang lebih tinggi dari profesi lingkungan keluarganya.

Pengaruh selfefficacy menunjukkan hasilnya yang semakin menurun, hal ini berarti lingkungan keluarga yang rendah akan membuat mahasiswa lebih berusaha semaksimal mungkin untuk meningkatkan kemampuannya agar lebih baik. Peningkatan kemampuan ini bertujuan untuk merubah kondisi dalam keluarga. Salah satunya yaitu dengan berprofesi sebagai guru, mereka beranggapan dengan menjadi guru akan kondisi mereka akan lebih sejahtera. Adanya keinginan untuk berprofesi menjadi guru akan menumbuhkan minat mahasiswa untuk berprofesi sebagai guru. Karena dengan berprofesi sebagai guru dipercaya dapat merubah keadaan keluarganya untuk menjadi lebih baik.

Berdasarkan hasil penelitian ini menunjukkan bahwa lingkungan keluarga melalui self efficacy tidak berpengaruh terhadap minat menjadi guru.Hasil penelitian ini menguatkan hasil penelitian Hikmah (2017) yang menjelaskan bahwa lingkungan keluarga berpengaruh negatif terhadap minat menjadi guru.Ditolaknya hipotesis ini didukung oleh teori Ryan dan Deci (2000) tentang SelfDetermination Theory yang diartikan sebagai rasa percaya bahwa seorang individu dapat mengendalikan dirinya sendiri.Keberhasilan suatu hal yang dilakukan oleh seseorang dapat dipengaruhi oleh faktor internal dan tidak dipengaruhi faktor eksternalnya, seperti lingkungan keluarga. 


\section{Pengaruh Self Efficacy terhadap Minat Menjadi Guru}

Hasil penelitian menunjukkan self efficacy berpengaruh positif terhadap minat menjadi gurumahasiswa pendidikan ekonomi FE UNNES sebesar 16,16\%. Hal ini membuktikan bahwa self efficacy berperan penting dalam meningkatkan kepercayaan diri atas kemampuan yang dimiliki mahasiswa untuk berprofesi sebagai guru. Semakin tinggi self efficacy maka semakin tinggi pula minat menjadi guru.

Adanya pengaruhself efficacy terhadap minat menjadi guru membuktikan kebenaran theory of planned behavior yang dikembangkan oleh Ajzen (2005) yang menjelaskan bahwa terdapat tiga hal yang mempengaruhi minat seseorang, salah satunya adalah kontrol perilaku persepsian (perceived behavior control). Kontrol perilaku persepsian merupakan kemudahan atau kesulitan untuk melakukan perilaku yang merefleksikan pengalaman masa lalu, hambatan, dan antisipasi dari hambatan tersebut.. Kontrol perilaku persepsian dihubungkan ke persepsi manusia mengenai kemudahan atau kesulitan dalam melakukan suatu perilaku yang diinginkan. Keyakinan diri (self efficacy) adalah persepsi mahasiswa terhadap kemudahan atau kesulitan untuk berprofesi menjadi guru.

Self efficacy diperlukan untuk meningkatkan kepercayaan diri mahasiswa, agar ketika mahasiswa sudah berprofesi sebagai guru dapat menghadapi situasi-situasi yang sulit dengan mudah nantinya. Sehingga ketika self efficacy yang timbul dari dalam diri mahasiswa itu tinggi, berarti mahasiswa juga sudah lebih siap untuk melaksanakan tugasnya sebagai guru setelah lulus nantinya. Hasil penelitian ini menguatkan hasil penelitian Astarini (2015) yang menunjukkan bahwa ada pengaruh self efficacy yang memberikan sumbangan sebesar $43,29 \%$ secara parsial berpengaruh terhadap minat menjadi guru. Sejalan dengan penelitian Cahyanto (2017) yang menyatakan bahwa terdapat pengaruh positif antara self efficacy secara parsial terhadap minat menjadi guru sebesar 3,72\%.

\section{SIMPULAN}

Penelitian ini menguji tentang pengaruh langsung maupun pengaruh tidak langsung motivasi diri dan lingkungan keluarga terhadap minat menjadi guru dengan self efficacy sebagai variabel mediasi. Ada pengaruh positif dan signifikan motivasi diri terhadap self efficacy sebesar $21,9 \%$, tanda positif artinya semakin tinggi motivasi diri maka akan semakin tinggi pula self efficacy pada mahasiswa pendidikan ekonomi FE UNNES. Ada pengaruh negatif dan signifikan lingkungan keluarga terhadap self efficacy sebesar $32,03 \%$, tanda negatif artinya semakin baik lingkungan keluarga maka akan semakin rendah self efficacy pada mahasiswa pendidikan ekonomi FE UNNES. Ada pengaruh tidak langsung antara motivasi diri melalui self efficacy terhadap minat menjadi guru sebesar $41,2 \%$ yang berarti bahwa semakin tinggi motivasi diri dengan diperkuat self efficacy maka akan semakin tinggi pengaruhnya terhadap minat menjadi guru pada mahasiswa pendidikan ekonomi FE UNNES. Ada pengaruh tidak langsung antara lingkungan keluarga melalui self efficacy terhadap minat menjadi guru sebesar $-20,38 \%$ yang berarti bahwa semakin baik lingkungan keluarga dengan diperkuat self efficacy maka akan semakin rendah pengaruhnya terhadap minat menjadi guru pada mahasiswa pendidikan ekonomi FE UNNES. Ada pengaruh positif dan signifikan self efficacy terhadap minat menjadi guru sebesar $16,16 \%$, tanda positif artinya semakin tinggi self efficacy maka akan semakin tinggi pula minat menjadi guru pada mahasiswa pendidikan ekonomi FE UNNES.

\section{DAFTAR PUSTAKA}

Ajzen, Icek. (2005). Attitudes, Personality, and Behavior. New York: University Press.

Alwisol.(2009). Psikologi Kepribadian. Malang: UMM Press.

Amir, Hermansyah.(2016). Korelasi Pengaruh Faktor Efikasi Diri terhadap Motivasi Berprestasi pada Mahasiswa Pendidikan Kimia Universitas 
Bengkulu.Manajer Pendidikan, Volume 10. No.4. Bengkulu: FKIP UNIB

Astarini, Ika. (2015). Pengaruh Self efficacy, Prestise Profesi Guru, dan Status Sosial Ekonomi Orang Tua terhadap Minat Menjadi Guru Akuntansi pada Mahasiswa Pendidikan Akuntansi 2011 FE UNNES. Economic Education Analysis Journal. Volume 4. No.2. Semarang: UNNES.

Dalyono, M. (2015).Psikologi Pendidikan. Jakarta: Rineka Cipta.

Djaali.(2013). Psikologi Pendidikan. Jakarta: Bumi Aksara

Febriyanto, Wahab Asyari.(2016). Pengaruh Prestasi Belajar, Pengalaman PPL, dan Lingkungan Keluarga terhadap Minat Menjadi Guru Akuntansi.Economic Education Analysis Journal, Volume 5 No.1. Semarang: UNNES.

Hamzah.(2008). Teori Motivasi dan Pengukurannya: Analisis di Bidang Pendidikan. Jakarta: Bumi Aksara.

Hikmah, Rizqi Khoirul. (2017). Peran Persepsi Kesejahteraan Guru dalam Memoderasi hubungan Persepsi tentang Profesi Guru dan Lingkungan Keluarga terhadap Minat Menjad Guru pada Mahasiswa Pendidikan Ekonomi. Economic Education Analysis Journal, Volume 3 No.1. Semarang: UNNES.

Jailani, Muhammad. (2017). Pengaruh Kewirausahaan, Motivasi Belajar, Sosial Ekonomi Orang Tua, dan Self Efficacy terhadap Minat Berwirausaha Siswa.Journal of Economic Education, Volume 6 No.1. Semarang: UNNES.

Lunenburg, Fred C. (2011). Self Efficacy in The Workplace: Implication for Motivation and Performance. International Journal of Management, Business, and Administration. Volume 14.No. 7.

Ryan, Richard $\mathrm{M}$ dan Edward L. Deci.(2000). Self-Determination Theory and The Facilitation of Intrinsic Motivation, Social Development, and Wellbeing.American Psycology, Volume 55. No.1.University of Rochester.
Setiaji, Khasan. (2015). Pilihan Karir Mengajar Mahasiswa Pendidikan Ekonomi (Kajian Motivasi Karir Mengajar, Career Self Efficacy, Status Sosial Ekonomi, Minat Menjadi Guru terhadap Prestasi Akademik).Dinamika Pendidikan, 10(2), 196-211.

Shalihah, Nafiatush. (2016). Determinan Minat Menjadi Guru Akuntansi.Economic Education Analysis Journal, Volume 3. No.1. Semarang: UNNES.

Subini, Nini. (2012). Psikologi Pembelajaran. Yogjakarta: Mentari Pustaka.

Slameto.(2010). Belajar dan Faktor yang Mempengaruhinya. Jakarta: Rineka Cipta.

Surya, Muhamad. (2013). Psikologi Guru Konsep dan Aplikasi. Bandung: Alfabeta.

Teintang, Yunemey, Jehosua. S.V. Sinolungan, dan Henry Opod. (2015). Sikap Orang Tua terhadap Pembentukan Kepribadian Anak pada Keluarga Petani Di Desa Talawaan Bantik Kecamatan Wori Kabupaten Minahasa Utara.Journal eBiomedik.Volume 3, Nomor 2.

Wahab, Rosmalina. (2015). Psikologi Belajar. Depok: Rajagrafindo Persada

Wahyudin, Agus. (2015). Metodolog Penelitian:Penelitian Bisnis dan Pendidikan. Semarang: Unnes Press.

Wildan, Muhammad, Susilaningsih, dan Elvia Ivada. (2016). Faktor-faktor yang Mempengaruhi Minat Mahasiswa Menjadi Guru pada Prodi Pendidikan Akuntansi FKIP UNS. Jurnal "Tata Arta" UNS, Volume 2. No.1. Surakarta: FKIP Universitas Sebelas Maret. 